British Journal of Psychiatry (1994), 165, 266-277

\title{
Correspondence
}

Contents: Strength of the genetic effect in schizophrenia/Cognitive-behavioural therapy for schizophrenia/Obsessive-compulsive symptoms and clozapine/Making the most of interpreters/ Prodromal symptoms of schizophrenia/High-dose antipsychotic medication/Epilepsy in Down's syndrome/Defeating depression in Zimbabwe/ Glucocorticoids, serotonin and mood/Seizures and antidepressants/Darier's disease cosegregating with affective disorder/Social competence and adolescent psychosis/ICD-10: a neuropsychiatrist's nightmare?/A catecholamine model of fatigue/ Dystonia induced by amphetamine and haloperidol/Adrenoceptor activity and adenylate cyclase inhibition in depression.

\section{Strength of the genetic effect in schizophrenia}

SIR: While one assumes that McGuffin et al (BJP, May 1994, 164, 593-599) set out to be provocative in maximising the genetic component while minimising the environmental component in the aetiology of schizophrenia, their paper cannot pass without comment.

Many of the conclusions they reach are based on concordance rates for schizophrenia of $46 \%$ between monozygotic twins. Clever formulae then boost their 'heritability' of schizophrenia to $89 \%$. It is now more than 20 years since Campion \& Tucker (1973) pointed out just how different monozygotic twins are, in that, compared with their dizygotic counterparts, they have lower birth weights and their perinatal death rate is three times higher. Reveley \& Reveley (1987) noted that twins are no longer regarded as a suitable population on whom to study the genetics of epilepsy or congenital abnormalities and that a concordant pair of schizophrenic twins "could be concordant equally on the basis of birth injury as on the basis of genetic predisposition".

Kendler et al (1993) used a preferable genetic method, in that they interviewed first-degree relatives of schizophrenic probands in Ireland. This study confirmed the indisputable genetic predisposition towards schizophrenia. Among the interviewed parents of schizophrenic people, $1.3 \%$ suffered from the disorder, as did $9.2 \%$ of siblings. Thus, while rates of schizophrenia were several times higher than among controls, schizophrenia among close relatives was relatively rare: in only $16 \%$ of families studied was there more than one schizophrenic individual.

Following their hypotheses on monozygotic twin concordance, McGuffin et al go on to describe 'stochastic' factors which appear to be genetic phenomena which provide sources of dissimilarity in genetically related individuals. Thus, while genetics explain concordance between monozygotic twins, they can also explain discordance. One should note that these stochastic events occur 'randomly', that is, independently from any environmental variable. At this point, I began to wonder if the paper had been intended for publication on April Fool's Day.

In the paper immediately before that of McGuffin et al, Crow (BJP, May 1994, 164, 588592) urges proponents of environmental aetiologies of schizophrenia to use "straightforward hypotheses and simple analyses" in support of their contentions. Perhaps the geneticists should also follow this advice.

CAMPION, E. \& TUCKER, G. (1973) A note on twin studies, schizophrenia and neurological impairment. Archives of General Psychiatry, 29, 460-464.

Kendler, K. S., McGutre, M., Gruenderg, A. M., el al (1993) The Roscommon Family Study. I. Methods, diagnosis of probands and risk of schizophrenia in relatives. Archives of General Psychiatry, 50, 527-540.

Reveley, A. M. \& Reveley, M. A. (1987) The relationship of twinning to the familial-sporadic distinction in schizophrenia. Journal of Psychiatric Research, 21, 515-520.

\section{Ross Clinic}

JOHN M. EAGLES

Aberdeen $A B 92 Z F$

\section{Cognitive-behavioural therapy for schizophrenia}

SIR: Kingdon et al (BJP, May 1994, 164, 581-587) overlook two problems in recommending cognitive-behavioural therapy (CBT) for schizophrenia. The first relates to the nature and origin 
of delusions, and the second relates to the appropriateness and validity of Beckian cognitive theory.

The literature on delusions and 'other abnormal beliefs' appears to have developed (Berrios, 1991) quite independently from the efforts in cognitive psychology to examine normal human thought processes, including belief formation (Schustack, 1991). Only recently have papers appeared examining cognitive processes in psychotic subjects which have respected the methodological frameworks of cognitive psychology (e.g. Huq et al, 1988). Such frameworks are essential to generate testable models of psychotic thought processes which can be easily proven wrong when the model is incorrect. The underlying problem appears to be the assumption that the delusion is a core pathology and not an epiphenomenon, as advocated by Bleuler (1911). The notion that simply talking the patient out of delusions is of any benefit is seriously misguided.

Beckian cognitive therapy is a pragmatic empirical treatment which has been shown to work in depression. However, the underlying theory has been less and less able to account for a number of clinical findings, leading to a "crisis of confidence" (Teasdale, 1993). Despite this 'crisis', Beckian CBT has been applied in more and more situations (Ross, 1991).

Simply using a treatment because it works can only be defended if at the same time efforts are made to understand why it works. The theoretical model of Beckian cognitive therapy for depression needs updating and validation before being applied elsewhere.

Berrios, G. E. (1991) Delusions as "wrong beliefs": a conceptual history. British Journal of Psychiatry, 159 (suppl. 14), 6-13.

Bleuler, E. (1911) Dementia Praecox or the Group of Schizophrenias (trans. J. Zinkin (1950)). New York: International Universities Press.

HuQ, S. F., GARETY, P. A. \& HemsLey, D. R. (1988) Probabilistic judgements in deluded and non-deluded subjects. Quarterly Journal of Experimental Psychology, 40, 801-812.

Ross, A. (1991) Growth without progress. Contemporary Psychology, 36, 743-744.

SchustaCk, M. W. (1991) Thinking about causality. In The Psychology of Human Thought (eds R. J. Sternberg \& E. E. Smith), pp. 92-115. Cambridge: Cambridge University Press.

Teasdale, J. D. (1993) Emotion and two kinds of meaning: cognitive therapy and applied cognitive science. Behaviour Research and Therapy, 31, 339-354.

Royal Edinburgh Hospital

D. A. Patience

Edinburgh EHIO $5 \mathrm{HF}$
Obsessive-compulsive symptoms and clozapine

SIR: Eales \& Layeni (BJP, May 1994, 164, 687688) present a case in which clozapine caused a significant exacerbation of obsessive-compulsive symptoms (OCS) in schizophrenia. This is not the first such case. One patient was reported by Cassady \& Thaker (1992), two by Patil (1992), five by Baker et al (1992), and two by Patel \& Tandon (1993).

The suggestion that the increased intensity of rituals is due to the $5-\mathrm{HT}_{2 \mathrm{~A}}$ receptor antagonist activity of clozapine is unlikely. Antipsychotic drugs such as pimozide, haloperidol, fluphenazine, loxapine, thioridazine have some antagonist activity at the 5-HT 2 receptors (Roth et al, 1992; Dursun \& Handley, 1992) but exacerbation or induction of OCS have not been reported after these drugs. Furthermore, selective 5-HT reuptake inhibitors-fluoxetine, paroxetine, fluvoxamine and citalopram - also block the 5-HT $\mathrm{HA}_{2 \mathrm{~A}}$ receptors (Johnson, 1991) but they improve OCS. However, $5-\mathrm{HT}_{2 \mathrm{C}}$ receptors have been implicated in obsessive-compulsive disorder (Kennett, 1993), and clozapine has the highest affinity for $5-\mathrm{HT}_{2 \mathrm{C}}$ receptors among antipsychotic drugs (Dursun \& Reveley, 1993). Chronic administration of clozapine blocks the 5- $\mathrm{HT}_{2 \mathrm{C}}$ receptors (Kuoppamaki et al, 1993), which may then lead to a state of denervation supersensitivity of these receptors. It may therefore be suggested that the hypersensitive $5-\mathrm{HT}_{2 \mathrm{C}}$ receptors may contribute to the exacerbation of OCS after clozapine.

Baker, R. W., Chengappa, K. N., Batrd, J. W., et al (1992) Emergence of obsessive compulsive symptoms during treatment with clozapine. Journal of Clinical Psychiatry, 53, 439-442.

Cassady, S. L. \& ThaKer, G. K. (1992) Addition of fluoxetine to clozapine. American Journal of Psychiatry, 149, 1274.

Dursun, S. M. \& HANDleY, S. L. (1992) Comparison of ritanserin, haloperidol, pimozide and clonidine on spontaneous and DOI head-shake. British Journal of Pharmacology, 105, 225P.

- \& Reveley, M. A. (1993) Clozapine has a unique pharmacological profile. British Medical Journal, 307, 200.

JoHnson, A. M. (1991) The comparative pharmacological properties of selective serotonin re-uptake inhibitors in animals. Perspectives in Psychiatry, 1, 37-70.

KENNETT, G. A. (1993) 5-HT 1 receptors and their therapeutic relevance. Current Opinion and Investigation in Drugs, 2, 317362.

Kuoppamaki, M., Seppala, T., Sylvalahti, E., et al (1993) Chronic clozapine treatment decreases 5-hydroxytryptamine-1C receptor density in the rat choroid plexus: comparison with haloperidol. Journal of Pharmacology and Experimental Therapeutics, 264, 1262-1267.

Patel, B. \& TANDON, R. (1993) Development of obsessive compulsive symptoms during clozapine treatment. American Journal of Psychiatry, 150, 836. 